\title{
Five layers of receptor signaling in $\gamma \delta$ T-cell differentiation and activation
}

\section{Sérgio T. Ribeiro, Julie C. Ribot and Bruno Silva-Santos*}

Faculdade de Medicina, Instituto de Medicina Molecular, Universidade de Lisboa, Lisboa, Portugal

\section{Edited by:}

Dieter Kabelitz, Christian-Albrechts

University Kiel, Germany

\section{Reviewed by:}

Sho Yamasaki, Kyushu University, Japan

Bernhard Moser, Cardiff University, UK

\section{*Correspondence:}

Bruno Silva-Santos, Faculdade de Medicina, Instituto de Medicina

Molecular, Universidade de Lisboa, Avenida Prof. Egas Moniz, Lisboa 1649-028, Portugal

e-mail: bssantos@medicina.ulisboa.pt
The contributions of $\gamma \delta$ T-cells to immunity to infection or tumors critically depend on their activation and differentiation into effectors capable of secreting cytokines and killing infected or transformed cells. These processes are molecularly controlled by surface receptors that capture key extracellular cues and convey downstream intracellular signals that regulate $\gamma \delta$ T-cell physiology. The understanding of how environmental signals are integrated by $\gamma \delta$ T-cells is critical for their manipulation in clinical settings. Here, we discuss how different classes of surface receptors impact on human and murine $\gamma \delta$ T-cell differentiation, activation, and expansion. In particular, we review the role of five receptor types: the T-cell receptor (TCR), costimulatory receptors, cytokine receptors, NK receptors, and inhibitory receptors. Some of the key players are the costimulatory receptors CD27 and CD28, which differentially impact on pro-inflammatory subsets of $\gamma \delta$ T-cells; the cytokine receptors IL-2R, IL-7R, and IL-15R, which drive functional differentiation and expansion of $\gamma \delta$ T-cells; the NK receptor NKG2D and its contribution to $\gamma \delta$ T-cell cytotoxicity; and the inhibitory receptors PD-1 and BTLA that control $\gamma \delta$ T-cell homeostasis. We discuss these and other receptors in the context of a five-step model of receptor signaling in $\gamma \delta$ T-cell differentiation and activation, and discuss its implications for the manipulation of $\gamma \delta$ T-cells in immunotherapy.

Keywords: $\gamma \delta$ T-cells, T-cell receptor, T-cell costimulation, cytokines, natural killer receptors

\section{INTRODUCTION}

$\gamma \delta$ cells endow the T-cell compartment with a rapid, innatelike reaction to insults, which places them in the afferent phase of the immune response. Namely, $\gamma \delta$ T-cells are responsible for "lymphoid stress surveillance," i.e., sensing and responding immediately to infections or non-microbial stress without the need of clonal expansion or de novo differentiation, in synchrony with prototypic innate immune responses (1). Critically, this implicates $\gamma \delta$ T-cells in inflammation (2), autoimmunity (3), infectious diseases $(4,5)$, and tumor surveillance $(6-8)$.

Many of the studies elucidating the physiological roles of $\gamma \delta$ T-cells have been performed in murine models, where a major breakthrough has been the identification of pro-inflammatory subsets naturally producing either IFN $\gamma$ or IL-17 (9-11). Moreover, these studies have been greatly facilitated by the identification of cell surface markers that segregate the two functional $\gamma \delta \mathrm{T}$ cell subsets: CD27, CD122, and NK1.1 mark IFN $\gamma$-producing $\gamma \delta$ cells, whereas their IL-17-expressing counterparts display a CD27$\mathrm{CCR}^{+}$phenotype (9-11). Moreover, the two subsets show distinct $V \gamma$ chain usage in their TCR repertoires, with a bias toward $\mathrm{V} \gamma 1$ among IFN $\gamma$-producing $\gamma \delta$ cells, and an enrichment in $\mathrm{V} \gamma 4$ and $\mathrm{V} \gamma 6$ in IL-17-producing $\gamma \delta$ cells (12).

In humans, $\gamma \delta$ T-cells are primarily identified by their $\mathrm{V} \delta$ chain usage, with $\mathrm{V} \delta 1^{+}$cells predominating in the thymus and in peripheral tissues, while $\mathrm{V} \delta 2^{+}$cells (mostly co-expressing a $V \gamma 9$ chain) constitute the majority of bloodcirculating $\gamma \delta$ T-cells. Both human $\gamma \delta$ T-cell subsets are highly prone to secrete IFN $\gamma$, but IL-17 can be induced in highly inflammatory conditions triggered by infections (13) or tumors $(14,15)$.

In both murine and human $\gamma \delta$ T-cells, functional responses are initiated upon recognition of antigens that are likely induced by stress signals and sensed by either T-cell or natural killer receptors. Some $\gamma \delta \mathrm{T}$-cell populations are also particularly responsive to cytokines or innate toll-like receptor (TLR) agonists (16, 17). Following proliferation and effector responses, the return to homeostasis is controlled by inhibitory receptors. Here, we discuss the various layers of contributions of T (TCR and costimulatory/inhibitory receptors), $\mathrm{NK}$, and cytokine receptors to the activation and differentiation of effector $\gamma \delta \mathrm{T}$-cell populations in mice and humans.

\section{SIGNAL 1: T-CELL RECEPTOR}

The $\gamma \delta$ TCR complex is composed by the $\gamma \delta$ TCR itself and various $\mathrm{CD} 3$ chains following the stoichiometry: TCR $\gamma \delta \mathrm{CD} 3 \varepsilon_{2} \gamma \delta \zeta_{2}$ in humans and TCR $\gamma \delta \mathrm{CD} 3 \varepsilon_{2} \gamma_{2} \zeta_{2}$ in mice (18). The assembly of a $\gamma \delta$ TCR complex in thymic progenitors has immediate consequences for $\gamma \delta$ T-cell development. The "strong" signals stemming from the $\gamma \delta$ TCR (when compared to the "weaker" pre-TCR signaling) drive $\gamma \delta / \alpha \beta$ common precursors into the $\gamma \delta$ lineage (19, $20)$. These "stronger" $\gamma \delta \mathrm{TCR}$ signals associate with increased phosphorylation of ERK1/2, abundant calcium release and induction of early growth response (Egr) transcription factors $(21,22)$.

The TCR complex does not present intrinsic kinase activity but the intracellular signaling is initiated after phosphorylation of immunoreceptor tyrosine-based activation motifs (ITAMs) in the 
CD3 cytoplasmic domains by the Src-family kinases (SFKs) Lck and Fyn (23). The recruitment of these SFKs to the TCR complex in $\gamma \delta \mathrm{T}$-cells remains obscure since these cells do not express the CD4 or CD8 co-receptors, which have been shown, in $\alpha \beta$ T-cells, to be responsible for recruiting SFKs upon $\alpha \beta$ TCR ligation (23). Nonetheless, the importance of SFKs in $\gamma \delta$ T-cells is underscored by the substantial phosphorylation of ERK upon inhibition of Csk, a potent inhibitor of SFKs (24).

SFK-mediated phosphorylation of the ITAMs on CD3 chains allows the recruitment, phospholylation, and activation of Zap70 that facilitates phosphorylation of the scaffolding proteins SLP76 and LAT. This lead to the formation of a supramolecular signalosome that recruits the phospholipase PLC $\gamma 1$, resulting in propagation of downstream signaling events (22). Here again, $\gamma \delta$ T-cell signaling is different from $\alpha \beta$ T-cells, since mutations on the binding site of PLC $\gamma 1$ on LAT resulted in a severe block in murine $\alpha \beta$ thymocyte development while $\gamma \delta$ T-cell numbers were only modestly reduced in the thymus, intestine, and liver, and remained normal in the skin. Unexpectedly, a population of $\gamma \delta$ T-cells in the secondary lymphoid organs in these mice underwent uncontrolled expansion and caused autoimmune pathology, suggesting distinct functions for LAT/PLC $\gamma 1$-mediated signaling in subpopulations of $\gamma \delta$ T-cells $(21,25)$.

In humans, the major $\gamma \delta \mathrm{T}$-cell subset in the peripheral blood, $\mathrm{V} \gamma 9 \mathrm{~V} \delta 2 \mathrm{~T}$-cells, are uniquely and specifically reactive to self- and foreign non-peptidic phosphorylated intermediates of isoprenoid synthesis - "phosphoantigens" or "phosphoagonists" (P-Ags) (2628). These P-Ags were shown to trigger bona fide V $\gamma 9 \mathrm{~V} \delta 2$ TCR signaling in various studies. Cipriani and colleagues showed that the activation of $\mathrm{V} \gamma 9 \mathrm{~V} \delta 2 \mathrm{~T}$-cells with the P-Ag isopentenyl pyrophosphate (IPP), induced rapid and persistent PKC-dependent phosphorylation of ERK1/2, p38 MAPK, and JNK, resulting in NF- $\mathrm{B}$ and AP-1 activation as well as the release of MIP- $1 \alpha$, MIP- $1 \beta$, IFN- $\gamma$, and TNF- $\alpha$ (29). Moreover, P-Ag stimulation and CD3crosslinking produced identical phosphorylation of the signaling proteins Zap70, PI3K, LAT, ERK1/2, and p38 MAPK $(30,31)$; and induced highly sustained calcium signaling in V $\gamma 9 \mathrm{~V} \delta 2 \mathrm{~T}$-cells (32). Importantly, activation by P-Ags is the basis of current cancer immunotherapy strategies involving V $\gamma 9 \mathrm{~V} \delta 2 \mathrm{~T}$-cells (33).

Recent work has produced some puzzling results on the role of the $\gamma \delta$ TCR in the development of effector subsets of murine $\gamma \delta$ T-cells (34-36), namely, CD27 ${ }^{+} \mathrm{CD} 122^{+} \gamma \delta \mathrm{T}$-cells producing IFN- $\gamma$ or $\mathrm{CD}^{-} 7^{-} \mathrm{CCR}^{+} \gamma \delta$ T-cells making IL-17 $(9,10)$. First, Chien and co-workers showed that T10/T22-specific $\gamma \delta$ T-cells required thymic expression of their TCR ligand to differentiate into IFN- $\gamma$ producers, in contrast with "ligand naïve" IL-17 producers (9). Consistent with this, TCR-dependent thymic selection was also shown to set the functional potential of dendritic epidermal T-cells (DETC) progenitors away from IL-17 production (37). Furthermore, peripheral IL-17-producing CD27- ${ }^{-} \mathrm{CR}^{+} \gamma \delta$ T-cells were shown to expand and produce IL-17 independently of TCR activation (38). However, a subsequent study by Chien and collaborators demonstrated that a subset of phycoerythrin (PE)-specific $\gamma \delta$ T-cells produced IL-17 specifically upon TCR ligation (39). Moreover, a recent study by Hayday and colleagues suggested that an impairment in Zap70 signaling (in SKG mice) mostly affected the development of IL- $17^{+}$rather than IFN- $\gamma^{+}$ $\gamma \delta$ T-cells (40). The authors further proposed that "innate-like" $\gamma \delta$ T-cell populations, including IL-17 producers and some subsets of IFN- $\gamma$ producers, receive strong TCR signals during thymic development to become hyporesponsive to TCR stimulation in the periphery (40). Future research should aim to resolve the apparent contradictions of the available data, namely, by clarifying the requirement on TCR ligand engagement, as well as the developmental effects of manipulating distinct $\gamma \delta$ TCR signaling pathways and their downstream (transcriptional and post-transcriptional) mechanisms on $\gamma \delta$ T-cell subsets.

\section{SIGNAL 2: COSTIMULATORY RECEPTORS}

A series of T-cell costimulatory receptors are known to induce qualitative and quantitative changes that lower activation thresholds, prevent "anergy" and enhance T-cell functions. Typical costimulatory receptors are type I transmembrane proteins that can be divided into two groups, based on their structural characteristics: immunoglobulin (Ig) or tumor necrosis factor receptor (TNFR) superfamilies. Ig superfamily members have a variable Ig-like extracellular domain and a short cytoplasmic tail, whereas TNFR family members present extracellular domains rich in six cysteine repeats (which form disulfide bridges) and a more complex cytoplasmic tail [reviewed in Ref. (41)]. These two main types of costimulatory receptors display different modes of intracellular signaling: whereas the CD28 family members associate directly with protein kinases (like PI3K or ITK), TNFR superfamily coreceptors require the adaptor proteins TRAF (TNFR-associated factor), namely TRAF2 and TRAF5, to link to downstream signaling mediators (Table 1). Here, based on their specific roles in $\gamma \delta$ T-cells, we shall discuss CD28 (of the Ig superfamily) and the TNFR superfamily members, CD27, CD30, and CD137 (4-1BB).

The best studied costimulatory receptor, CD28, has historically yielded paradoxical results on $\gamma \delta$ T-cells (46). We have recently readdressed this issue for both human and mouse $\gamma \delta \mathrm{T}$-cells. We described that CD28 is constitutively expressed on lymphoid $\gamma \delta \mathrm{T}$ cells and promotes survival and proliferation via IL-2 production. CD28 receptor agonists enhanced $\gamma \delta$ T-cell expansion, which was conversely inhibited by blocking antibodies against its B7 ligands (42). Importantly, CD28-deficient mice displayed lower (relative to controls) numbers of total or activated $\gamma \delta$ T-cells upon Plasmodium berghei infection, and failed to expand both their IFN $-\gamma^{+}$and IL- $17^{+}$subsets (42). In contrast, Hayes and colleagues reported that both functional $\gamma \delta$ T-cell subsets differentiated and expanded normally in a Listeria model (80). It would be interesting to determine how variable is the dependence on CD28 costimulation for $\gamma \delta$ T-cell responses to distinct infectious agents.

In naïve mice, while CD28 is not required for the development of either IFN- $\gamma^{+}$or IL- $17^{+} \gamma \delta$ T-cell subsets (80), the TNFR superfamily member CD27 is selectively implicated in the generation of IFN $-\gamma^{+} \gamma \delta$ T-cells (10). In fact, we showed that CD27 expression segregates IFN- $\gamma^{+}\left(\mathrm{CD} 27^{+}\right)$and IL-17 ${ }^{+}\left(\mathrm{CD} 27^{-}\right) \gamma \delta \mathrm{T}$-cells. Most interestingly, these phenotypes are established in the thymus, and since embryonic stages. Based on the results from our (10) and Chien's (9) teams, the development of IFN- $\gamma$-producing $\gamma \delta$ T-cells seemingly requires strong TCR signaling and CD27 costimulation in the thymus. 
Table 1 | Co-receptors of $\gamma \delta$ T-cells - extracellular ligands and intracellular signaling pathways

\begin{tabular}{|c|c|c|c|c|c|}
\hline Receptor & Ligands & $\begin{array}{l}\text { Intracellular signaling } \\
\text { initiators/adaptors }\end{array}$ & $\begin{array}{l}\text { Downstream signaling } \\
\text { pathway }\end{array}$ & Target molecules & Reference \\
\hline CD28 & $\begin{array}{l}\mathrm{B} 7.1(\mathrm{CD} 80) \\
\mathrm{B} 7.2(\mathrm{CD} 86)\end{array}$ & $\begin{array}{l}\text { PI3K } \\
\text { ITK } \\
\text { Grb2 }\end{array}$ & $\begin{array}{l}\text { PI3K/AKT } \\
\text { Grb2/MEK/ERK }\end{array}$ & $\begin{array}{l}\text { IL-2, NF-KB, AP-1, Bcl- } \mathrm{x}_{\mathrm{L}} \\
\text { NFAT }\end{array}$ & $(42-45)$ \\
\hline $\mathrm{CD} 27$ & CD70 & $\begin{array}{l}\text { TRAF2 } \\
\text { TRAF5 } \\
\text { Siva }\end{array}$ & $\begin{array}{l}\text { IKK/NF-KB } \\
\text { JNK }\end{array}$ & $\begin{array}{l}\text { NF-kB, } \mathrm{Ca}^{2+}, \text { cyclinD2, } \\
\text { Bcl2a1, Bcl-x } \mathrm{L}\end{array}$ & $(46-49)$ \\
\hline CD30 & CD30L & $\begin{array}{l}\text { TRAF2 } \\
\text { TRAF5 }\end{array}$ & $\begin{array}{l}\text { TRAF/IKK/lkB } \\
\mathrm{Ca}^{2+}\end{array}$ & $\begin{array}{l}\text { NF-kB, IL-4, IFN } \gamma, \text { IL-8, CC } \\
\text { chemokines }\end{array}$ & $(46,50,51)$ \\
\hline $\begin{array}{l}\text { 4-1BB } \\
\text { (CD137) }\end{array}$ & CD137L & TRAF2 & & $N F-\kappa B, I F N \gamma$ & $(52-54)$ \\
\hline IL-7R & IL-7 & $\begin{array}{l}\text { Jak1 } \\
\text { Jak3 }\end{array}$ & STAT3 & IL-17, SOCS3 & (59) \\
\hline IL-21R & IL-21 & $\begin{array}{l}\text { Jak1 } \\
\text { Jak3 }\end{array}$ & STAT3 & $\begin{array}{l}\text { CXCL13, } \\
\text { CXCR5 }\end{array}$ & (60) \\
\hline NKG2D & $\begin{array}{l}\text { MIC(A-B) } \\
\text { ULBP (1-6) } \\
\text { H60 } \\
\text { MULT1 } \\
\text { RAE1 }\end{array}$ & DAP10 & $\begin{array}{l}\text { PI3K/AKT } \\
\text { Grb2NAV1/SOS1 } \\
\text { PKC } \theta / \mathrm{Ca}^{2+}\end{array}$ & NF-אB, RelB, Bcl-xL, Bcl-2 & $(32,46,61-63)$ \\
\hline PD-1 & $\begin{array}{l}\text { PD-L1 (B7-H1) } \\
\text { PD-L2 (B7-DC) }\end{array}$ & $\begin{array}{l}\text { SHP-1 } \\
\text { SHP-2 }\end{array}$ & $\begin{array}{l}\text { CK2/PTEN/PI3K/AKT } \\
\text { MEK/ERK }\end{array}$ & $\begin{array}{l}\text { GSK-3, Bcl-xL Smad3, } \\
\text { Cdc25A, IFN } \gamma, \text { IL-2 }\end{array}$ & $(73-76)$ \\
\hline BTLA & HVEM & $\begin{array}{l}\text { SHP-1 } \\
\text { SHP-2 }\end{array}$ & Zap70/ERK & IL-17, TNF, IL-2 & $(77-79)$ \\
\hline
\end{tabular}

Beyond its role in thymic differentiation, CD27 is critical for the expansion of peripheral IFN- $\gamma$-producing $\gamma \delta$ T-cells upon infection with herpes viruses or malaria parasites in mice (81). We showed that, in the context of TCR stimulation and upon ligation to CD70, CD27 signaling activates the non-canonical NF- $\mathrm{B}$ pathway and enhances the expression of anti-apoptotic and cell cycle-related genes, thus promoting murine $\gamma \delta$ T-cell survival and proliferation (81).

We have also addressed the impact of CD27 costimulation on the activation of human $\gamma \delta$ T-cells. Administration of soluble recombinant CD70 enhanced, whereas anti-CD27 (or antiCD70) antibodies reduced, $\mathrm{V} \gamma 9 \mathrm{~V} \delta 2 \mathrm{~T}$-cell expansion in vitro (82).
Moreover, CD27 signals induced calcium fluxes and upregulated the expression of Cyclin D2 and the anti-apoptotic gene Bcl2a1. Given the typical IFN- $\gamma$ secretion and cytotoxicity of activated $\mathrm{V} \gamma 9 \mathrm{~V} \delta 2$ T-cells (30), our work suggests that the modulation of CD70-CD27 signals may be beneficial in the context of $\gamma \delta$ T-cell-based cancer immunotherapy.

Upon activation, human $\gamma \delta \mathrm{T}$-cells can also express another TNFR superfamily member, CD30 (83). CD30 signaling, which potentiated calcium fluxes induced by TCR activation, also enhanced pro-inflammatory cytokine production (50). Recently, Yoshikai and colleagues compared $\gamma \delta$ T-cell homeostasis and response to Listeria monocytogenes in CD30-sufficient versus 
deficient mice. They demonstrated a selective depletion of IL-17producing $\mathrm{V} \gamma 6^{+} \mathrm{T}$-cells in mucosal tissues in the steady-state and upon infection (84). This associated with reduced bacterial clearance, which could be rescued, alongside the IL- $17^{+} \mathrm{V} \gamma 6^{+} \mathrm{T}$-cell pool, by agonistic anti-CD30 antibody administration. In contrast, Lee et al. reported that agonistic anti-CD137 (4-1BB) antibodies promoted the expansion of IFN- $\gamma^{+} \mathrm{V} \gamma 1^{+} \mathrm{T}$-cells, which protected (in an IFN- $\gamma$-dependent manner) also from Listeria infection (52). This study also showed that $4-1 \mathrm{BB}$ was expressed and functional on activated human $\gamma \delta$ T-cells, and its ligation upon cell transfer protected NOD/SCID mice against Listeria infection.

Interestingly, activated $\mathrm{V} \gamma 9 \mathrm{~V} \delta 2 \mathrm{~T}$-cells also express high levels of 4-1BBL (CD137L) (85), which besides acting as a ligand for $4-1 \mathrm{BB}$ on $\mathrm{T}$ and NK-cells, may also participate in $\mathrm{V} \gamma 9 \mathrm{~V} \delta 2 \mathrm{~T}$-cell activation due to its known reverse signaling ability (86). This may, in fact, also apply to CD70 (CD27-ligand), which is highly induced upon phosphoantigen-mediated stimulation of $\mathrm{V} \gamma 9 \mathrm{~V} \delta 2$ T-cells $(82,87)$. These possibilities deserve further investigation.

\section{SIGNAL 3: CYTOKINE RECEPTORS}

Interleukins are key determinants of T-cell survival, proliferation, and differentiation. IL-7, IL-15, and IL-2 are essential for lymphocyte development and homeostasis; upon inflammation, other cytokines, namely, IL-1 $\beta$, IL-12, IL-18, IL-21, and IL-23, take a central role in determining T-cell functions. Here, we review the main contributions of homeostatic and inflammatory cytokines specifically to $\gamma \delta \mathrm{T}$-cell physiology.

IL-7 and IL-15 are seemingly the key determinants of murine $\gamma \delta$ T-cell development (88-90) and homeostasis (91). A recent study that depleted IL-7 specifically from $\left(\right.$ Foxn $1^{+}$) thymic epithelial cells showed that $\gamma \delta$ T-cells were significantly reduced in the adult thymus and in the gut, whereas they were completely absent in the fetal thymus and epidermis (89). In the dermis, it was also IL-7, but not IL-15, that supported the development and survival of the resident $\gamma \delta$ T-cell population (92). Conversely, in the gut, IL-15 seems to play the primordial role in sustaining the local intraepithelial $\gamma \delta$ T-cell compartment (93).

Unexpectedly, IL-7 was recently reported to promote the selective expansion of murine IL-17-producing $\gamma \delta$ T-cells (59). STAT3-dependent IL-7 signals allowed CD27 ${ }^{-} \gamma \delta$ T-cells to resist activation-induced cell death (AICD) and undergo proliferative responses to TCR agonists. Such an IL-7/IL-17 axis was also reported to be required for the $\gamma \delta \mathrm{T}$-cell response to viral hepatitis infection in vivo (94). Moreover, IL-7 also seems to support the expansion of human IL-17-producing $\gamma \delta$ T-cells (59).

We recently assessed the functional differentiation of human $\gamma \delta$ thymocytes, which are $>80 \%$ of the $V \delta 1$ subtype. We observed that IL-15 and IL-2, but not IL-7, induced the cytotoxic type 1 (IFN- $\gamma$-producing) program in functionally immature $\gamma \delta$ thymocytes (55). This was consistent with previous data on peripheral $\gamma \delta$ T-cells isolated from cancer patients (95). However, additional reports on peripheral $\mathrm{V} \gamma 9 \mathrm{~V} \delta 2 \mathrm{~T}$-cell cultures showed that IL-15 or IL-2 stimulation, despite efficient ERK and AKT activation, were not sufficient to induce effector responses; these required phosphoantigen-dependent TCR activation and downstream calcium mobilization $(56,96)$. Unexpectedly, in our cultures of $\gamma \delta$ (mostly V 11 ) thymocytes, TCR stimulation was not required for neither ERK activation nor T-bet and eomesodermin induction and the acquisition of effector functions (55).

IL-2 and IL-15 play key roles in the peripheral expansion of $\mathrm{V} \gamma 9 \mathrm{~V} \delta 2 \mathrm{~T}$-cells in response to microbial phosphoantigens or synthetic drugs like bisphosphonates $(56,97)$. This notwithstanding, it is important to note, toward the therapeutic application of $\mathrm{V} \gamma 9 \mathrm{~V} \delta 2 \mathrm{~T}$-cells, that optimal effector responses seemingly require the combination of these cytokines with TCR agonists. Thus, recent work from Chen and colleagues demonstrated that the differentiation of cytotoxic type $1 \mathrm{~V} \gamma 9 \mathrm{~V} \delta 2 \mathrm{~T}$-cells capable of controlling Mycobacterium tuberculosis infection in macaques required a phosphoantigen/IL-2 combination (98).

Effector $\gamma \delta \mathrm{T}$-cell differentiation is also greatly impacted by inflammatory cytokines, particularly IL-12 and IL-18 that typically promote IFN- $\gamma$ production; and IL- $1 \beta$ and IL- 23 that mostly drive IL-17 production.

High expression of IL-12R $\beta$ expression on activated murine $\gamma \delta$ T-cells guarantees a dominance of type $1\left(\right.$ IFN- $\left.\gamma^{+}\right)$over type 2 $\left(\mathrm{IL}-4^{+}\right.$) effector fates (99). Type 1 differentiation is also predominant in human $\gamma \delta \mathrm{T}$-cells, and can be further enhanced by IL-18 $(100,101)$ or IL-21 (102). The induction of a type 17 program in human $\gamma \delta$ T-cells requires persistent stimulation with IL-23 for neonatal V $\gamma 9 \mathrm{~V} \delta 2$ T-cells (15); and IL-23 and IL- $1 \beta$ in the presence of TGF- $\beta$ for adult V $\gamma 9 \mathrm{~V} \delta 2$ T-cells $(13,103)$. In mice, IL- $1 \beta$ and IL-23 are also the main drivers of abundant IL-17 production by peripheral $\gamma \delta$ T-cells $(3,5,81,104-106)$, although recent data surprisingly suggest that IL-18 can replace IL- $1 \beta$ in combining with IL-23 to induce IL-17 expression (107). In contrast, IL-1 $\beta$ upstream of IL-1R seems essential for GM-CSF production by $\gamma \delta$ T-cells (108).

Finally, IL-21 was recently suggested to endow human $\mathrm{V} \gamma 9 \mathrm{~V} \delta 2$ T-cells with B-cell helper activity associated with a $\mathrm{T}$ follicular helper cell-like phenotype $(60,109)$, which may impact on the generation of high affinity antibodies against microbial infections.

\section{SIGNAL 4: NATURAL KILLER RECEPTORS}

An important key characteristic that allows the recognition of transformed cells by $\gamma \delta$ T-cells is the expression of a wide set of germline-encoded receptors that were initially described in NKcells and hence are collectively known as NK receptors (NKRs), including natural cytotoxicity receptors (NCRs).

The C-type lectin-like NK receptor group 2 member D (NKG2D) is the best studied NKR in $\gamma \delta$ T-cells. NKG2D binds extracellularly to multiple ligands of the MIC(A-B) and ULBP (1-6) families in humans; and to H60, MULT1, and various RAE1 molecules in mice (110). NKG2D ligands are induced upon cellular stress, for example, downstream of the DNA-damage response pathway in tumor cells $(111,112)$. The biological significance of this recognition system is underlined by the increased susceptibility of NKG2D-deficient mice to tumor development (113).

Intracellularly, NKG2D binds to DNAX-activating protein of $10 \mathrm{kDa}$ (DAP10), which carries an YXNM motif that after tyrosine phosphorylation recruits PI3K or a Grb2-Vav1-SOS1 signaling complex (Table 1). This motif is similar to that in CD28, and thus, NKG2D/DAP10 may provide T-cells with costimulatory signals that synergize with the ITAM-based TCR/CD3 complex (61). However, unlike $\alpha \beta$ T-cells but similarly to NK-cells, $\gamma \delta$ T-cells can 
express both DAP10 and DAP12 (62). The latter contains an ITAM motif, which after tyrosine phosphorylation recruits and activates Syk and ZAP70. Interestingly, only murine but not human NKG2D is able to associate with DAP12 (in addition to DAP10).

The controversy on a primary stimulatory versus costimulatory role of NKG2D in $\gamma \delta$ T-cells has been discussed elsewhere $(46,114)$. Briefly, the costimulatory function of NKG2D in human V $\gamma 9 \mathrm{~V} \delta 2$ T-cells was supported by additive effects on TCR-mediated activation: an upregulation of cytokine production upon MICA-NKG2D interactions (115); and an increase in intracellular calcium mobilization and cytotoxic activity (32). However, other lines of evidence have suggested that NKG2D signals can activate $\gamma \delta$ T-cells in the absence of TCR engagement: NKG2D ligation can upregulate CD69 expression in V $\gamma 9 \mathrm{~V} 82 \mathrm{~T}$-cells to similar extent as TCR stimulation (116); NKG2D but not TCR blockade can inhibit $\mathrm{V} \gamma 9 \mathrm{~V} \delta 2$ T-cell cytotoxicity against various hematological tumors (117); and murine DETC can target tumors upon recognition of NKG2D ligands $(6,118)$.

Another NKR implicated in tumor cell recognition by $\mathrm{V} \gamma 9 \mathrm{~V} \delta 2$ T-cells is DNAX accessory molecule-1 (DNAM-1). DNAM-1 is an Ig-like family glycoprotein composed of a cytoplasmic domain containing three putative sites of phosphorylation by intracellular kinases. The phosphorylation of the Ser329 by protein kinase C (PKC) was shown to be critical for the association between DNAM-1 and LFA-1, which recruits the Fyn Src kinase to phosphorylate the Tyr322 of DNAM-1, thus initiating downstream signaling leading to SLP-76 and Vav1 phosphorylation (Table 1) (119). Antibody-mediated DNAM-1 blockade impaired V $\gamma 9 \mathrm{~V} \delta 2$ T-cell cytotoxicity and IFN- $\gamma$ production against hepatocellular carcinoma lines expressing Nectin-like-5 (71).

Recently, we characterized a $\mathrm{V} \delta 1^{+} \mathrm{T}$-cell population capable of targeting hematological tumors resistant to fully activated $\mathrm{V} \gamma 9 \mathrm{~V} \delta 2$ T-cells (120). Unexpectedly, the enhanced killer function resulted from induced NCR expression, namely NKp30 and NKp44, which had been previously regarded as NK-specific markers. Although neither $\mathrm{V} \delta 1^{+}$nor $\mathrm{V} \delta 2^{+}$cells express NCRs constitutively, these can be upregulated selectively in V $\delta 1^{+}$cells by PI3K/AKT-dependent signals provided by $\gamma c$ cytokines (IL-2 or IL-15) and TCR stimulation. Once expressed on the cell surface, NKp30 and NKp44 can signal via $\mathrm{CD} 3 \zeta$ and DAP12, respectively (64). We further showed that NKp30 and NKp44 are both functional in $\mathrm{NCR}^{+} \mathrm{V} \delta 1^{+} \mathrm{T}$ cells and synergize with NKG2D to target lymphocytic leukemia cells (120).

In sum, NKRs seem critical for tumor recognition and deployment of the cytotoxic program that is endowed by $\mathrm{TCR} / \gamma \mathrm{c}$ cytokine-dependent differentiation, thus defining distinct mechanisms to be integrated in $\gamma \delta$ T-cell-mediated cancer immunotherapy.

\section{SIGNAL 5: INHIBITORY RECEPTORS}

Beyond efficient activation and deployment of effector functions, it is necessary to negatively regulate the T-cell response in order to return to the homeostatic baseline. Inhibitory receptors like PD-1 or CTLA-4 are known to be critical for this contracting phase of the T-cell response and have become major clinical targets in cancer immunotherapy. Although $\gamma \delta$ T-cells rarely express CTLA-4, they can upregulate PD-1 upon activation, while they constitutively express BTLA, and thus these two receptors may be the key to control $\gamma \delta$ T-cell responses.

Programed death-1 (PD-1) is absent or low expressed on circulating V $\gamma 9 \mathrm{~V} 82 \mathrm{~T}$-cells but is rapidly induced upon activation (121). The cytoplasmic tail of PD-1 contains conserved immunoreceptor tyrosine-based inhibitory motif (ITIM) and switch motif (ITSM), both of which are phosphorylated to recruit negative regulators that block Lck activity downstream of the TCR complex (122). Moreover, PD-1 ligation can augment the activity of the protein phosphatase and tensin homolog (PTEN), a cellular phosphatase that inhibits PI3K/AKT signaling and thus leads to impaired survival, proliferation, and IL-2 release (123). The expression of the ligand PD-L1 on tumor cells inhibited V $\gamma 9 \mathrm{~V} \delta 2$ T-cell cytotoxicity and IFN- $\gamma$ production (121). However, zoledronate-induced accumulation of P-Ags in tumor cells and consequent $\mathrm{V} \gamma 9 \mathrm{~V} \delta 2$ TCR activation seemed to overcome the inhibitory effect of PD1/PD-L1 interactions. More research is required to understand the full extent to what PD-1 may control $\gamma \delta$ T-cell functions and homeostasis.

B- and T-lymphocyte attenuator (BTLA) is another inhibitory receptor, member of the $\mathrm{CD} 28$ family and structurally related to PD-1 and CTLA-4. Binding to its ligand, herpesvirus entry mediator (HVEM), induces phosphorylation of the ITIM domain and association with $\mathrm{SH} 2$ domain-containing protein tyrosine phosphatase 1 (SHP-1) and SHP-2, which leads to attenuation of cellular activation and growth (124). Recent data showed that BTLA engagement with HVEM reduced P-Ag/TCR-mediated signaling and inhibited $\mathrm{V} \gamma 9 \mathrm{~V} \delta 2 \mathrm{~T}$-cell proliferation, including in response to lymphoma cells (77). Conversely, BTLA-HVEM blockade using monoclonal antibodies enhanced $\mathrm{V} \gamma 9 \mathrm{~V} \delta 2 \mathrm{TCR}$ signaling and may thus have therapeutic potential for the positive manipulation of $\gamma \delta$ T-cells.

A detailed study on BTLA function in murine $\gamma \delta$ T-cells has revealed a selective involvement in the homeostasis of the IL17-producing CD27 ${ }^{-} \gamma \delta$ T-cell subset (78). Although these cells constitutively express low levels of BTLA, it is upregulated by IL-7 stimulation and thereby limits $\gamma \delta$ T-cell numbers. Consequently, BTLA-deficient mice accumulated IL- $17^{+} \mathrm{CD} 27^{-} \gamma \delta$ T-cells and were more susceptible (than wild-type controls) to dermatitis, which could be reversed by agonist BTLA antibodies. Thus, BTLA may be an important target for controlling pathogenic $\gamma \delta$ T-cells in inflammatory and autoimmune diseases.

\section{CONCLUDING REMARKS}

A multitude of surface receptors has been shown to participate in $\gamma \delta \mathrm{T}$-cell differentiation and activation. However, some crucial aspects remain to be elucidated, such as the identity of most $\gamma \delta$ TCR ligands. Most importantly, we must improve the transfer of past and current basic research into future protocols for $\gamma \delta \mathrm{T}$ cell-based immunotherapy. In this context, some key questions are: how to balance $\gamma \delta$ TCR activation with "exhaustion" due to chronic stimulation? What can be achieved by manipulating the NK-like activation mode of $\gamma \delta$ T-cells? Which costimulatory receptors should be modulated, and at what stages, to boost the desired $\gamma \delta$ T-cell responses? Which combinations of cytokines enable the best effector $\gamma \delta$ T-cells for each therapeutic application? Which receptors are most useful to tune down or switch off pathogenic effector 
$\gamma \delta$ T-cells? The answers to these questions must be obtained in appropriate in vivo pre-clinical models and hopefully next in the clinic.

For now, we would like to propose that the five types of receptor signals reviewed here define five distinct layers of regulation of $\gamma \delta$ T-cell differentiation, activation, and function. The $\gamma \delta$ TCR is critical for the initial stages of differentiation and for proliferative responses; both processes further require cytokine signals that promote cell survival, proliferation, and terminal effector function. Costimulatory and inhibitory receptors control the extent of $\gamma \delta$ T-cell expansion, with interesting biases toward specific effector subsets. Finally, NK receptors play a decisive role in tumor cell targeting by $\gamma \delta$ T-cells. Thus, we believe that the recognition of "stressed self" can be mediated by the $\gamma \delta$ TCR but also chiefly by NK receptors like NKG2D. As such, the characterization of both type of ligands on tumors may be critical to design protocols, select and monitor patients, and increase the chances of efficacious $\gamma \delta$ T-cell-based cancer immunotherapies.

\section{ACKNOWLEDGMENTS}

We thank Daniel Correia for helpful discussions on these topics. Our work is supported by Fundação para a Ciência e Tecnologia (SFRH/BD/84123/2012 to Sérgio T. Ribeiro; SFRH/BPD/78135/2011 and EXPL/IMI-IMU/0170/2013 to Julie C. Ribot) and European Research Council (StG_260352 to Bruno Silva-Santos).

\section{REFERENCES}

1. Hayday AC. $\gamma \delta$ T cells and the lymphoid stress-surveillance response. Immunity (2009) 31:184-96. doi:10.1016/j.immuni.2009.08.006

2. Martin B, Hirota K, Cua DJ, Stockinger B, Veldhoen M. Interleukin-17producing $\gamma \delta \mathrm{T}$ cells selectively expand in response to pathogen products and environmental signals. Immunity (2014) 31:321-30. doi:10.1016/j.immuni. 2009.06.020

3. Sutton CE, Lalor SJ, Sweeney CM, Brereton CF, Lavelle EC, Mills KHG. Interleukin-1 and IL-23 induce innate IL-17 production from $\gamma \delta \mathrm{T}$ cells, amplifying Th17 responses and autoimmunity. Immunity (2009) 31:331-41. doi:10.1016/j.immuni.2009.08.001

4. Ramsburg E, Tigelaar R, Craft J, Hayday A. Age-dependent requirement for gammadelta $\mathrm{T}$ cells in the primary but not secondary protective immune response against an intestinal parasite. J Exp Med (2003) 198:1403-14. doi:10.1084/jem.20030050

5. Lockhart E, Green AM, Flynn JL. IL-17 production is dominated by gammadelta T cells rather than CD4 T cells during Mycobacterium tuberculosis infection. J Immunol (2006) 177:4662-9. doi:10.4049/jimmunol.177.7.4662

6. Girardi M, Oppenheim DE, Steele CR, Lewis JM, Glusac E, Filler R, et al. Regulation of cutaneous malignancy by gammadelta T cells. Science (2001) 294:605-9. doi:10.1126/science.1063916

7. Gao Y, Yang W, Pan M, Scully E, Girardi M, Augenlicht LH, et al. Gamma delta $\mathrm{T}$ cells provide an early source of interferon gamma in tumor immunity. J Exp Med (2003) 198:433-42. doi:10.1084/jem.20030584

8. Lança T, Costa MF, Gonçalves-Sousa N, Rei M, Grosso AR, Penido C, et al. Protective role of the inflammatory CCR2/CCL2 chemokine pathway through recruitment of type 1 cytotoxic $\gamma \delta$ T lymphocytes to tumor beds. J Immunol (2013) 190:6673-80. doi:10.4049/jimmunol.1300434

9. Jensen KDC, Su X, Shin S, Li L, Youssef S, Yamasaki S, et al. Thymic selection determines gammadelta $\mathrm{T}$ cell effector fate: antigen-naive cells make interleukin-17 and antigen-experienced cells make interferon gamma. Immunity (2008) 29:90-100. doi:10.1016/j.immuni.2008.04.022

10. Ribot JC, deBarros A, Pang DJ, Neves JF, Peperzak V, Roberts SJ, et al. CD27 is a thymic determinant of the balance between interferon-gamma- and interleukin 17-producing gammadelta T cell subsets. Nat Immunol (2009) 10:427-36. doi:10.1038/ni.1717
11. Haas JD, González FHM, Schmitz S, Chennupati V, Föhse L, Kremmer E, et al. CCR6 and NK1.1 distinguish between IL-17A and IFN-gammaproducing gammadelta effector T cells. Eur J Immunol (2009) 39:3488-97. doi:10.1002/eji.200939922

12. O'Brien RL, Born WK. gammadelta T cell subsets: a link between TCR and function? Semin Immunol (2010) 22:193-8. doi:10.1016/j.smim.2010.03.006

13. Caccamo N, La Mendola C, Orlando V, Meraviglia S, Todaro M, Stassi G, et al. Differentiation, phenotype, and function of interleukin-17-producing human Vgamma9Vdelta2 T cells. Blood (2011) 118:129-38. doi:10.1182/blood-201101-331298

14. Wu P, Wu D, Ni C, Ye J, Chen W, Hu G, et al. $\gamma \delta \mathrm{T} 17$ cells promote the accumulation and expansion of myeloid-derived suppressor cells in human colorectal cancer. Immunity (2014) 40:785-800. doi:10.1016/j.immuni.2014.03.013

15. Moens E, Brouwer M, Dimova T, Goldman M, Willems F, Vermijlen D. IL-23R and TCR signaling drives the generation of neonatal Vgamma9Vdelta2 $\mathrm{T}$ cells expressing high levels of cytotoxic mediators and producing IFN-gamma and IL-17. J Leukoc Biol (2011) 89:743-52. doi:10.1189/jlb.0910501

16. Bonneville M, O'Brien RL, Born WK. Gammadelta T cell effector functions: a blend of innate programming and acquired plasticity. Nat Rev Immunol (2010) 10:467-78. doi:10.1038/nri2781

17. Chien Y, Meyer C, Bonneville M. $\gamma \delta \mathrm{T}$ cells: first line of defense and beyond. Annu Rev Immunol (2014) 32:121-55. doi:10.1146/annurevimmunol-032713-120216

18. Siegers GM, Swamy M, Fernández-Malavé E, Minguet S, Rathmann S, Guardo AC, et al. Different composition of the human and the mouse gammadelta $\mathrm{T}$ cell receptor explains different phenotypes of CD3gamma and CD3delta immunodeficiencies. J Exp Med (2007) 204:2537-44. doi:10.1084/ jem.20070782102207c

19. Hayes SM, Li L, Love PE. TCR signal strength influences alphabeta/gammadelta lineage fate. Immunity (2005) 22:583-93. doi:10.1016/j. immuni.2005.03.014

20. Haks MC, Lefebvre JM, Lauritsen JPH, Carleton M, Rhodes M, Miyazaki T, et al. Attenuation of gammadeltaTCR signaling efficiently diverts thymocytes to the alphabeta lineage. Immunity (2005) 22:595-606. doi:10.1016/j.immuni. 2005.04.003

21. Hayes SM, Shores EW, Love PE. An architectural perspective on signaling by the pre-, alphabeta and gammadelta T cell receptors. Immunol Rev (2003) 191:28-37. doi:10.1034/j.1600-065X.2003.00011.x

22. Smith-Garvin JE, Koretzky GA, Jordan MS. T cell activation. Annu Rev Immunol (2009) 27:591-619. doi:10.1146/annurev.immunol.021908.132706

23. Kuhns MS, Badgandi HB. Piecing together the family portrait of TCR-CD3 complexes. Immunol Rev (2012) 250:120-43. doi:10.1111/imr.12000

24. Tan YX, Manz BN, Freedman TS, Zhang C, Shokat KM, Weiss A. Inhibition of the kinase Csk in thymocytes reveals a requirement for actin remodeling in the initiation of full TCR signaling. Nat Immunol (2014) 15:186-94. doi:10.1038/ni.2772

25. Sullivan SA, Zhu M, Bao S, Lewis CA, Ou-Yang C, Zhang W. The role of LAT-PLC $\gamma 1$ interaction in $\gamma \delta \mathrm{T}$ cell development and homeostasis. J Immunol (2014) 192:2865-74. doi:10.4049/jimmunol.1302493

26. Constant P, Davodeau F, Peyrat M, Poquet Y, Puzo G, Bonneville M, et al. Stimulation of human gamma delta $\mathrm{T}$ cells by nonpeptidic mycobacterial ligands. Science (1994) 264:267-70. doi:10.1126/science.8146660

27. Tanaka Y, Morita CT, Nieves E, Brenner MB, Bloom BR. Natural and synthetic non-peptide antigens recognized by human gamma delta T cells. Nature (1995) 375:155-8. doi:10.1038/375155a0

28. Gober H-J, Kistowska M, Angman L, Jeno P, Mori L, De Libero G. Human T cell receptor $\gamma \delta$ cells recognize endogenous mevalonate metabolites in tumor cells. J Exp Med (2003) 197:163-8. doi:10.1084/jem.20021500

29. Cipriani B, Knowles H, Chen L, Battistini L, Brosnan CF. Involvement of classical and novel protein kinase $\mathrm{C}$ isoforms in the response of human $\mathrm{V} \gamma 9 \mathrm{~V} \delta 2 \mathrm{~T}$ cells to phosphate antigens. J Immunol (2002) 169:5761-70. doi:10.4049/jimmunol.169.10.5761

30. Correia DV, D’Orey F, Cardoso BA, Lança T, Grosso AR, DeBarros A, et al. Highly active microbial phosphoantigen induces rapid yet sustained MEK/Erkand PI-3K/Akt-mediated signal transduction in anti-tumor human $\gamma \delta$ T-cells. PLoS One (2009) 4:e5657. doi:10.1371/journal.pone.0005657

31. Nedellec S, Bonneville M, Scotet E. Human Vgamma9Vdelta2 T cells: from signals to functions. Semin Immunol (2010) 22:199-206. doi:10.1016/j.smim. 2010.04.004 
32. Nedellec S, Sabourin C, Bonneville M, Scotet E. NKG2D costimulates human $\mathrm{V} \gamma 9 \mathrm{~V} \delta 2 \mathrm{~T}$ cell antitumor cytotoxicity through protein kinase $\mathrm{C} \theta$-dependent modulation of early TCR-induced calcium and transduction signals. J Immunol (2010) 185:55-63. doi:10.4049/jimmunol.1000373

33. Gomes A, Martins D, Silva-Santos B. Targeting $\gamma \delta \mathrm{T}$ lymphocytes for cancer immunotherapy from novel mechanistic insight to clinical application. Cancer Res (2010) 70:10024-7. doi:10.1158/0008-5472.CAN-10-3236

34. Turchinovich G, Pennington D. T cell receptor signalling in $\gamma \delta$ cell development: strength isn't everything. Trends Immunol (2011) 32:567-73. doi:10. 1016/j.it.2011.09.005

35. Chien Y, Zeng X, Prinz I. The natural and the inducible: interleukin (IL)-17producing $\gamma \delta$ T cells. Trends Immunol (2013) 34:151-4. doi:10.1016/j.it.2012. 11.004

36. Fahl SP, Coffey F, Wiest DL. Origins of $\gamma \delta \mathrm{T}$ cell effector subsets: a riddle wrapped in an enigma. J Immunol (2014) 193:4289-94. doi:10.4049/jimmunol. 1401813

37. Turchinovich G, Hayday AC. Skint-1 identifies a common molecular mechanism for the development of interferon- $\gamma$-secreting versus interleukin-17secreting $\gamma \delta$ T cells. Immunity (2011) 35:59-68. doi:10.1016/j.immuni.2011. 04.018

38. Kapsenberg ML. Gammadelta T cell receptors without a job. Immunity (2009) 31:181-3. doi:10.1016/j.immuni.2009.08.004

39. Zeng X, Wei Y-L, Huang J, Newell EW, Yu H, Kidd BA, et al. $\gamma \delta$ T cells recognize a microbial encoded B cell antigen to initiate a rapid antigen-specific interleukin17 response. Immunity (2012) 37:524-34. doi:10.1016/j.immuni.2012.06.011

40. Wencker M, Turchinovich G, Di Marco Barros R, Deban L, Jandke A, Cope A, et al. Innate-like $\mathrm{T}$ cells straddle innate and adaptive immunity by altering antigen-receptor responsiveness. Nat Immunol (2014) 15:80-7. doi:10.1038/ ni.2773

41. Duttagupta PA, Boesteanu AC, Katsikis PD. Costimulation signals for memory CD8+ T cells during viral infections. Crit Rev Immunol (2009) 29:469-86. doi:10.1615/CritRevImmunol.v29.i6.20

42. Ribot JC, DeBarros A, Mancio-Silva L, Pamplona A, Silva-Santos B. B7-CD28 costimulatory signals control the survival and proliferation of murine and human $\gamma \delta$ T cells via interleukin-2 production. J Immunol (2012) 189:1202-8. doi:10.4049/jimmunol.1200268

43. Kane LP, Andres PG, Howland KC, Abbas AK, Weiss A. Akt provides the CD28 costimulatory signal for up-regulation of IL-2 and IFN-gamma but not TH2 cytokines. Nat Immunol (2001) 2:37-44. doi:10.1038/83144

44. Takeda K, Harada Y, Watanabe R, Inutake Y, Ogawa S, Onuki K, et al. CD28 stimulation triggers NF-kappaB activation through the CARMA1-PKCthetaGrb2/Gads axis. Int Immunol (2008) 20:1507-15. doi:10.1093/intimm/dxn108

45. Watanabe R, Harada Y, Takeda K, Takahashi J, Ohnuki K, Ogawa S, et al. Grb2 and Gads exhibit different interactions with CD28 and play distinct roles in CD28-mediated costimulation. J Immunol (2006) 177:1085-91. doi:10.4049/jimmunol.177.2.1085

46. Ribot JC, Debarros A, Silva-Santos B. Searching for "signal 2": costimulation requirements of $\gamma \delta \mathrm{T}$ cells. Cell Mol Life Sci (2011) 68:2345-55. doi:10.1007/s00018-011-0698-2

47. Gravestein LA, Amsen D, Boes M, Calvo CR, Kruisbeek AM, Borst J. The TNF receptor family member CD27 signals to Jun N-terminal kinase via Traf-2. Eur J Immunol (1998) 28:2208-16. doi:10.1002/(SICI)1521-4141(199807)28: 07<2208::AID-IMMU2208>3.0.CO;2-L

48. Denoeud J, Moser M. Role of CD27/CD70 pathway of activation in immunity and tolerance. J Leukoc Biol (2011) 89:195-203. doi:10.1189/jlb.0610351

49. Xue L, Chu F, Cheng Y, Sun X, Borthakur A, Ramarao M, et al. Siva-1 binds to and inhibits BCL-X(L)-mediated protection against UV radiation-induced apoptosis. Proc Natl Acad Sci U S A (2002) 99:6925-30. doi:10.1073/pnas. 102182299

50. Biswas P, Rovere P, De Filippi C, Heltai S, Smith C, Dagna L, et al. Engagement of CD30 shapes the secretion of cytokines by human gamma delta T cells. Eur J Immunol (2000) 30:2172-80. doi:10.1002/1521-4141(2000)30:18<2172::AIDIMMU2172>3.0.CO;2-5

51. Biswas P, Mantelli B, Delfanti F, Ferrarini M, Poli G, Lazzarin A. CD30 ligation differentially affects CXCR4-dependent HIV-1 replication and soluble CD30 secretion in non-Hodgkin cell lines and in gamma delta T lymphocytes. Eur J Immunol (2003) 33:3136-45. doi:10.1002/eji.200324344
52. Lee SJ, Kim YH, Hwang SH, Kim YI, Han IS, Vinay DS, et al. 4-1BB signal stimulates the activation, expansion, and effector functions of $\gamma \delta \mathrm{T}$ cells in mice and humans. Eur J Immunol (2013) 43:1839-48. doi:10.1002/eji.201242842

53. Wang C, Lin GHY, McPherson AJ, Watts TH. Immune regulation by $4-1 \mathrm{BB}$ and 4-1BBL: complexities and challenges. Immunol Rev (2009) 229:192-215. doi:10.1111/j.1600-065X.2009.00765.x

54. Jang IK, Lee ZH, Kim YJ, Kim SH, Kwon BS. Human 4-1BB (CD137) signals are mediated by TRAF2 and activate nuclear factor-kappa B. Biochem Biophys Res Commun (1998) 242:613-20. doi:10.1006/bbrc.1997.8016

55. Ribot JC, Ribeiro ST, Correia DV, Sousa AE, Silva-Santos B. Human thymocytes are functionally immature and differentiate into cytotoxic type 1 effector T cells upon IL-2/IL-15 signaling. J Immunol (2014) 192(5):2237-43. doi:10.4049/jimmunol.1303119

56. García VE, Jullien D, Song M, Uyemura K, Shuai K, Morita CT, et al. IL-15 enhances the response of human gamma delta T cells to nonpeptide [correction of nonpetide] microbial antigens. J Immunol (1998) 160:4322-9.

57. Li H, David Pauza C. Interplay of T-cell receptor and interleukin-2 signalling in V $\gamma 2$ V 82 T-cell cytotoxicity. Immunology (2011) 132:96-103. doi:10.1111/j. 1365-2567.2010.03343.x

58. Liao W, Lin J-X, Leonard WJ. Interleukin-2 at the crossroads of effector responses, tolerance, and immunotherapy. Immunity (2013) 38:13-25. doi:10.1016/j.immuni.2013.01.004

59. Michel ML, Pang DJ, Haque SF, Potocnik AJ, Pennington DJ, Hayday AC. Interleukin 7 (IL-7) selectively promotes mouse and human IL-17-producing gammadelta cells. Proc Natl Acad Sci U S A (2012) 109:17549-54. doi:10.1073/pnas. 1204327109

60. Bansal RR, Mackay CR, Moser B, Eberl M. IL-21 enhances the potential of human $\gamma \delta \mathrm{T}$ cells to provide B-cell help. Eur J Immunol (2012) 42:110-9. doi:10.1002/eji.201142017

61. Long EO. Versatile signaling through NKG2D. Nat Immunol (2002) 3:1119-20. doi:10.1038/ni1202-1119

62. Lanier LL. DAP10- and DAP12-associated receptors in innate immunity. Immunol Rev (2009) 227:150-60. doi:10.1111/j.1600-065X.2008.00720.x

63. Poggi A, Zancolli M, Boero S, Catellani S, Musso A, Zocchi MR. Differential survival of $\gamma \delta \mathrm{T}$ cells, $\alpha \beta \mathrm{T}$ cells and NK cells upon engagement of NKG2D by NKG2DL-expressing leukemic cells. Int J Cancer (2011) 129:387-96. doi:10.1002/ijc.25682

64. Hudspeth K, Silva-Santos B, Mavilio D. Natural cytotoxicity receptors: broader expression patterns and functions in innate and adaptive immune cells. Front Immunol (2013) 4:69. doi:10.3389/fimmu.2013.00069

65. Brandt CS, Baratin M, Yi EC, Kennedy J, Gao Z, Fox B, et al. The B7 family member B7-H6 is a tumor cell ligand for the activating natural killer cell receptor NKp30 in humans. J Exp Med (2009) 206:1495-503. doi:10.1084/jem.20090681

66. Martinet L, Jean C, Dietrich G, Fournié J-J, Poupot R. PGE2 inhibits natural killer and gamma delta T cell cytotoxicity triggered by NKR and TCR through a cAMP-mediated PKA type I-dependent signaling. Biochem Pharmacol (2010) 80:838-45. doi:10.1016/j.bcp.2010.05.002

67. Hudspeth K, Fogli M, Correia DV, Mikulak J, Roberto A, Della Bella S, et al. Engagement of NKp30 on V $81 \mathrm{~T}$ cells induces the production of CCL3, CCL4, and CCL5 and suppresses HIV-1 replication. Blood (2012) 119:4013-6. doi:10.1182/blood-2011-11-390153

68. Baychelier F, Sennepin A, Ermonval M, Dorgham K, Debré P, Vieillard V. Identification of a cellular ligand for the natural cytotoxicity receptor NKp44. Blood (2013) 122:2935-42. doi:10.1182/blood-2013-03-489054

69. Vieillard V, Baychelier F, Debré P. NKp44L: a new tool for fighting cancer. Oncoimmunology (2014) 3:e27988. doi:10.4161/onci.27988

70. McVicar DW, Taylor LS, Gosselin P, Willette-Brown J, Mikhael AI, Geahlen RL, et al. DAP12-mediated signal transduction in natural killer cells. A dominant role For The Syk protein-tyrosine kinase. J Biol Chem (1998) 273:32934-42. doi:10.1074/jbc.273.49.32934

71. Toutirais O, Cabillic F, Le Friec G, Salot S, Loyer P, Le Gallo M, et al. DNAX accessory molecule-1 (CD226) promotes human hepatocellular carcinoma cell lysis by Vgamma9Vdelta2 T cells. Eur J Immunol (2009) 39:1361-8. doi:10.1002/eji.200838409

72. Long EO, Kim HS, Liu D, Peterson ME, Rajagopalan S. Controlling natural killer cell responses: integration of signals for activation and inhibition. Annu Rev Immunol (2013) 31:227-58. doi:10.1146/annurev-immunol-020711-075005 
73. Parry RV, Chemnitz JM, Frauwirth KA, Lanfranco AR, Braunstein I, Kobayashi SV, et al. CTLA-4 and PD-1 receptors inhibit T-cell activation by distinct mechanisms. Mol Cell Biol (2005) 25:9543-53. doi:10.1128/MCB.25.21.9543-9553. 2005

74. Chemnitz JM, Parry RV, Nichols KE, June CH, Riley JL. SHP-1 and SHP-2 associate with immunoreceptor tyrosine-based switch motif of programmed death 1 upon primary human $\mathrm{T}$ cell stimulation, but only receptor ligation prevents $\mathrm{T}$ cell activation. J Immunol (2004) 173:945-54. doi:10.4049/jimmunol.173.2.945

75. Patsoukis N, Li L, Sari D, Petkova V, Boussiotis VA. PD-1 increases PTEN phosphatase activity while decreasing PTEN protein stability by inhibiting CK2. Mol Cell Biol (2013) 33:3091-8. doi:10.1128/MCB.00319-13

76. Patsoukis N, Brown J, Petkova V, Liu F, Li L, Boussiotis VA. Selective effects of PD-1 on Akt and Ras pathways regulate molecular components of the cell cycle and inhibit T cell proliferation. Sci Signal (2012) 5:ra46. doi:10.1126/scisignal. 2002796

77. Gertner-dardenne J, Fauriat C, Orlanducci F, Thibult M, Pastor S, Fitzgibbon $\mathrm{J}$, et al. The co-receptor BTLA negatively regulates human $\mathrm{V} \gamma 9 \mathrm{~V} \delta 2 \mathrm{~T}$-cell proliferation: a potential way of immune escape for lymphoma cells. Blood (2013) 122:922-31. doi:10.1182/blood-2012-11-464685

78. Bekiaris V, Sedý JR, Macauley MG, Rhode-Kurnow A, Ware CF. The inhibitory receptor BTLA controls $\gamma \delta \mathrm{T}$ cell homeostasis and inflammatory responses. Immunity (2013) 39:1082-94. doi:10.1016/j.immuni.2013.10.017

79. Watanabe N, Gavrieli M, Sedy JR, Yang J, Fallarino F, Loftin SK, et al. BTLA is a lymphocyte inhibitory receptor with similarities to CTLA-4 and PD-1. Nat Immunol (2003) 4:670-9. doi:10.1038/ni944

80. Laird RM, Wolf BJ, Princiotta MF, Hayes SM. $\gamma \delta$ T cells acquire effector fates in the thymus and differentiate into cytokine-producing effectors in a Listeria model of infection independently of CD28 costimulation. PLoS One (2013) 8:e63178. doi:10.1371/journal.pone.0063178

81. Ribot JC, Chaves-Ferreira M, D’Orey F, Wencker M, Gonçalves-Sousa N, Decalf $\mathrm{J}$, et al. Cutting edge: adaptive versus innate receptor signals selectively control the pool sizes of murine IFN- $\gamma$ - or IL-17-producing $\gamma \delta$ T cells upon infection. J Immunol (2010) 185:6421-5. doi:10.4049/jimmunol.1002283

82. DeBarros A, Chaves-Ferreira M, D’Orey F, Ribot JC, Silva-Santos B. CD70CD27 interactions provide survival and proliferative signals that regulate $\mathrm{T}$ cell receptor-driven activation of human gammadelta peripheral blood lymphocytes. Eur J Immunol (2011) 41:195-201. doi:10.1002/eji.201040905

83. Ferrarini M, Delfanti F, Gianolini M, Rizzi C, Alfano M, Lazzarin A, et al. NF-кB modulates sensitivity to apoptosis, proinflammatory and migratory potential in short- versus long-term cultured human $\gamma \delta$ lymphocytes. J Immunol (2008) 181:5857-64. doi:10.4049/jimmunol.181.9.5857

84. Sun X, Shibata K, Yamada H, Guo Y, Muta H, Podack ER, et al. CD30L/CD30 is critical for maintenance of IL-17A-producing $\gamma \delta \mathrm{T}$ cells bearing $\mathrm{V} \gamma 6$ in mucosa-associated tissues in mice. Mucosal Immunol (2013) 6:1191-201. doi:10.1038/mi.2013.18

85. Maniar A, Zhang X, Lin W, Gastman BR, Pauza CD, Strome SE, et al. Human gammadelta $\mathrm{T}$ lymphocytes induce robust NK cell-mediated antitumor cytotoxicity through CD137 engagement. Blood (2010) 116:1726-33. doi:10.1182/blood-2009-07-234211

86. Shao Z, Schwarz H. CD137 ligand, a member of the tumor necrosis factor family, regulates immune responses via reverse signal transduction. J Leukoc Biol (2011) 89:21-9. doi:10.1189/jlb.0510315

87. Brandes M, Willimann K, Lang AB, Nam K-H, Jin C, Brenner MB, et al. Flexible migration program regulates gamma delta $\mathrm{T}$-cell involvement in humoral immunity. Blood (2003) 102:3693-701. doi:10.1182/blood-2003-04-1016

88. Malissen M, Pereira P, Gerber DJ, Malissen B, DiSanto JP. The common cytokine receptor gamma chain controls survival of gamma/delta T cells. J Exp Med (1997) 186:1277-85. doi:10.1084/jem.186.8.1277

89. Shitara S, Hara T, Liang B, Wagatsuma K, Zuklys S, Holländer GA, et al. IL7 produced by thymic epithelial cells plays a major role in the development of thymocytes and TCR $\gamma \delta+$ intraepithelial lymphocytes. J Immunol (2013) 190:6173-9. doi:10.4049/jimmunol.1202573

90. He YW, Malek TR. Interleukin-7 receptor alpha is essential for the development of gamma delta + T cells, but not natural killer cells. J Exp Med (1996) 184:289-93. doi:10.1084/jem.184.1.289

91. Baccala R, Witherden D, Gonzalez-Quintial R, Dummer W, Surh CD, Havran WL, et al. Gamma delta T cell homeostasis is controlled by IL-7 and IL15 together with subset-specific factors. J Immunol (2005) 174:4606-12. doi:10.4049/jimmunol.174.8.4606
92. Sumaria N, Roediger B, Ng LG, Qin J, Pinto R, Cavanagh LL, et al. Cutaneous immunosurveillance by self-renewing dermal gammadelta T cells. J Exp Med (2011) 208:505-18. doi:10.1084/jem.20101824

93. Zhao H, Nguyen H, Kang J. Interleukin 15 controls the generation of the restricted $\mathrm{T}$ cell receptor repertoire of gamma delta intestinal intraepithelial lymphocytes. Nat Immunol (2005) 6:1263-71. doi:10.1038/ni1267

94. Hou L, Jie Z, Desai M, Liang Y, Soong L, Wang T, et al. Early IL-17 production by intrahepatic $\mathrm{T}$ cells is important for adaptive immune responses in viral hepatitis. J Immunol (2013) 190:621-9. doi:10.4049/jimmunol.1201970

95. Yamaguchi T, Suzuki Y, Katakura R, Ebina T, Yokoyama J, Fujimiya Y. Interleukin-15 effectively potentiates the in vitro tumor-specific activity and proliferation of peripheral blood $\gamma \delta \mathrm{T}$ cells isolated from glioblastoma patients. Cancer Immunol Immunother (1998) 47:97-103. doi:10.1007/ s002620050509

96. Li H, Pauza CD. HIV envelope-mediated, CCR5/ $\alpha 4 \beta 7$-dependent killing of CD4-negative $\gamma \delta \mathrm{T}$ cells which are lost during progression to AIDS. Blood (2011) 118:5824-31. doi:10.1182/blood-2011-05-356535

97. Casetti R, Perretta G, Taglioni A, Mattei M, Colizzi V, Dieli F, et al. Drug-induced expansion and differentiation of Vgamma9Vdelta2 $\mathrm{T}$ cells in vivo: the role of exogenous IL-2. J Immunol (2005) 175:1593-8. doi:10.4049/jimmunol.175.3. 1593

98. Chen CY, Yao S, Huang D, Wei H, Sicard H, Zeng G, et al. Phosphoantigen/IL2 expansion and differentiation of $\mathrm{V} \gamma 2 \mathrm{~V} \delta 2 \mathrm{~T}$ cells increase resistance to tuberculosis in nonhuman primates. PLoS Pathog (2013) 9:e1003501. doi:10.1371/journal.ppat.1003501

99. Yin Z, Zhang DH, Welte T, Bahtiyar G, Jung S, Liu L, et al. Dominance of IL-12 over IL-4 in gamma delta $\mathrm{T}$ cell differentiation leads to default production of IFN-gamma: failure to down-regulate IL-12 receptor beta 2-chain expression. J Immunol (2000) 164:3056-64. doi:10.4049/jimmunol.164.6.3056

100. Li W, Kubo S, Okuda A, Yamamoto H, Ueda H, Tanaka T, et al. Effect of IL18 on expansion of gammadelta T cells stimulated by zoledronate and IL-2. J Immunother (2010) 33:287-96. doi:10.1097/CJI.0b013e3181c80ffa

101. Tsuda J, Li W, Yamanishi H, Yamamoto H, Okuda A, Kubo S, et al. Involvement of CD56brightCD11c+ cells in IL-18-mediated expansion of human $\gamma \delta$ T cells. J Immunol (2011) 186:2003-12. doi:10.4049/jimmunol.1001919

102. Thedrez A, Harly C, Morice A, Salot S, Bonneville M, Scotet E. IL-21-mediated potentiation of antitumor cytolytic and proinflammatory responses of human $\mathrm{V}$ gamma 9V delta $2 \mathrm{~T}$ cells for adoptive immunotherapy. J Immunol (2009) 182:3423-31. doi:10.4049/jimmunol.0803068

103. Ness-Schwickerath KJ, Jin C, Morita CT. Cytokine requirements for the differentiation and expansion of IL-17A- and IL-22-producing human Vgamma2Vdelta2 T cells. J Immunol (2010) 184:7268-80. doi:10.4049/ jimmunol.1000600

104. Duan J, Chung H, Troy E, Kasper DL. Microbial colonization drives expansion of IL-1 receptor 1-expressing and IL-17-producing gamma/delta T cells. Cell Host Microbe (2010) 7:140-50. doi:10.1016/j.chom.2010.01.005

105. Shibata K, Yamada H, Hara H, Kishihara K, Yoshikai Y. Resident Vdelta1+ gammadelta $\mathrm{T}$ cells control early infiltration of neutrophils after Escherichia coli infection via IL-17 production. J Immunol (2007) 178:4466-72. doi:10. 4049/jimmunol.178.7.4466

106. Riol-Blanco L, Lazarevic V, Awasthi A, Mitsdoerffer M, Wilson BS, Croxford A, et al. IL-23 receptor regulates unconventional IL-17-producing T cells that control bacterial infections. J Immunol (2010) 184:1710-20. doi:10.4049/ jimmunol.0902796

107. Lalor SJ, Dungan LS, Sutton CE, Basdeo SA, Fletcher JM, Mills KHG. Caspase1-processed cytokines IL-1beta and IL-18 promote IL-17 production by gammadelta and CD4 T cells that mediate autoimmunity. J Immunol (2011) 186:5738-48. doi:10.4049/jimmunol.1003597

108. Lukens JR, Barr MJ, Chaplin DD, Chi H, Kanneganti T-D. Inflammasomederived IL- $1 \beta$ regulates the production of GM-CSF by CD4(+) T cells and $\gamma \delta$ T cells. J Immunol (2012) 188:3107-15. doi:10.4049/jimmunol.1103308

109. Caccamo N, Todaro M, La Manna MP, Sireci G, Stassi G, Dieli F. IL-21 regulates the differentiation of a human $\gamma \delta$ T cell subset equipped with B cell helper activity. PLoS One (2012) 7:e41940. doi:10.1371/journal.pone.0041940

110. Eagle RA, Trowsdale J. Promiscuity and the single receptor: NKG2D. Nat Rev Immunol (2007) 7:737-44. doi:10.1038/nri2144

111. Gasser S, Orsulic S, Brown EJ, Raulet DH. The DNA damage pathway regulates innate immune system ligands of the NKG2D receptor. Nature (2005) 436:1186-90. doi:10.1038/nature03884 
112. Champsaur M, Lanier LL. Effect of NKG2D ligand expression on host immune responses. Immunol Rev (2010) 235:267-85. doi:10.1111/j.0105-2896.2010. 00893.x

113. Guerra N, Tan YX, Joncker NT, Choy A, Gallardo F, Xiong N, et al. NKG2Ddeficient mice are defective in tumor surveillance in models of spontaneous malignancy. Immunity (2008) 28:571-80. doi:10.1016/j.immuni.2008.02.016

114. Correia DV, Lopes A, Silva-Santos B. Tumor cell recognition by $\gamma \delta \mathrm{T}$ lymphocytes: T-cell receptor vs. NK-cell receptors. Oncoimmunology (2013) 2:e22892. doi:10.4161/onci.22892

115. Das H, Groh V, Kuijl C, Sugita M, Morita CT, Spies T, et al. MICA engagement by human Vgamma2Vdelta2 $\mathrm{T}$ cells enhances their antigen-dependent effector function. Immunity (2001) 15:83-93. doi:10.1016/S1074-7613(01) 00168-6

116. Rincon-Orozco B, Kunzmann V, Wrobel P, Kabelitz D, Steinle A, Herrmann T. Activation of V gamma 9V delta $2 \mathrm{~T}$ cells by NKG2D. J Immunol (2005) 175:2144-51. doi:10.4049/jimmunol.175.4.2144

117. Lança T, Correia DV, Moita CF, Raquel H, Neves-Costa A, Ferreira C, et al. The MHC class Ib protein ULBP1 is a nonredundant determinant of leukemia/lymphoma susceptibility to gammadelta T-cell cytotoxicity. Blood (2010) 115:2407-11. doi:10.1182/blood-2009-08-237123

118. Nitahara A, Shimura H, Ito A, Tomiyama K, Ito M, Kawai K. NKG2D ligation without $\mathrm{T}$ cell receptor engagement triggers both cytotoxicity and cytokine production in dendritic epidermal T cells. J Invest Dermatol (2006) 126:1052-8. doi:10.1038/sj.jid.5700112

119. De Andrade LF, Smyth MJ, Martinet L. DNAM-1 control of natural killer cells functions through nectin and nectin-like proteins. Immunol Cell Biol (2014) 92:237-44. doi:10.1038/icb.2013.95

120. Correia DV, Fogli M, Hudspeth K, da Silva MG, Mavilio D, Silva-Santos B. Differentiation of human peripheral blood V $\delta 1+\mathrm{T}$ cells expressing the natural cytotoxicity receptor NKp30 for recognition of lymphoid leukemia cells. Blood (2011) 118:992-1001. doi:10.1182/blood-2011-02-339135
121. Iwasaki M, Tanaka Y, Kobayashi H, Murata-Hirai K, Miyabe H, Sugie T, et al. Expression and function of PD-1 in human $\gamma \delta \mathrm{T}$ cells that recognize phosphoantigens. Eur J Immunol (2011) 41:345-55. doi:10.1002/eji.201040959

122. Kulpa DA, Lawani M, Cooper A, Peretz Y, Ahlers J, Sékaly R-P. PD-1 coinhibitory signals: the link between pathogenesis and protection. Semin Immunol (2013) 25:219-27. doi:10.1016/j.smim.2013.02.002

123. Pedoeem A, Azoulay-Alfaguter I, Strazza M, Silverman GJ, Mor A. Programmed death-1 pathway in cancer and autoimmunity. Clin Immunol (2014) 153:145-52. doi:10.1016/j.clim.2014.04.010

124. McGrath MM, Najafian N. The role of coinhibitory signaling pathways in transplantation and tolerance. Front Immunol (2012) 3:47. doi:10.3389/fimmu. 2012.00047

Conflict of Interest Statement: Bruno Silva-Santos is a co-founder and share holder of LymphAct S.A. The other co-authors declare that the research was conducted in the absence of any commercial or financial relationships that could be construed as a potential conflict of interest.

Received: 21 October 2014; accepted: 08 January 2015; published online: 26 January 2015.

Citation: Ribeiro ST, Ribot JC and Silva-Santos B (2015) Five layers of receptor signaling in $\gamma \delta$ T-cell differentiation and activation. Front. Immunol. 6:15. doi: 10.3389/fimmu.2015.00015

This article was submitted to T Cell Biology, a section of the journal Frontiers in Immunology.

Copyright (c) 2015 Ribeiro, Ribot and Silva-Santos. This is an open-access article distributed under the terms of the Creative Commons Attribution License (CC BY). The use, distribution or reproduction in other forums is permitted, provided the original author(s) or licensor are credited and that the original publication in this journal is cited, in accordance with accepted academic practice. No use, distribution or reproduction is permitted which does not comply with these terms. 